\title{
Fourier Transform Infrared Determination of Imidacloprid in Pesticide Formulations
}

\author{
Guillermo Quintás, Sergio Armenta, Salvador Garrigues* and Miguel de la Guardia \\ Department of Analytical Chemistry, University of Valencia, Edifici Jeroni Muñoz, $50^{\text {th }}$ Dr. Moliner, \\ 46100 Burjassot, Valencia, Spain
}

\begin{abstract}
Foi desenvolvido um método simples usando Infra-Vermelho com Transformada de Fourier (IRFT) para a determinação de Imidaclopride em formulações pesticidas. As amostram foram diluídas com $\mathrm{CHCl}_{3}$ e os espectros de IRFT de amostras e padrões foram obtidos numa resolução nominal de $4 \mathrm{~cm}^{-1}$, entre 4000 e $900 \mathrm{~cm}^{-1}$, com acumulação de 25 espectros. A determinação de Imidaclopride foi feita medindo-se tanto a área do sinal obtido entre 1577 e $1567 \mathrm{~cm}^{-1}$ ou a altura do sinal a $1572 \mathrm{~cm}^{-1}$, ambos com correção de linha base horizontal a $1900 \mathrm{~cm}^{-1}$. Os limites de detecção atingidos da ordem de $9 \mu \mathrm{g} \mathrm{g}^{-1}$, foram apropriados para a determinação de Imidoclopride em formulações comercias disponíveis. Os resultados com IRFT forma estatisticamente comparáveis àqueles encontrados para Cromatografia Líquida de Alta Performance (HPLC). O procedimento desenvolvido reduz o consumo de solventes orgânicos por preparação de amostra, de $53 \mathrm{~mL}$ de $\mathrm{CH}_{3} \mathrm{CN}$ requeridos com HPLC para $2,5 \mathrm{~mL}$ de $\mathrm{CHCl}_{3}$, reduzindo o descarte gerado, e aumenta a frequiência de medidas de 10 para 60 amostras $\mathrm{h}^{-1}$, quando comparado ao método de referência usando HPLC-UV.
\end{abstract}

A simple method has been developed for Fourier Transform Infrared (FTIR) determination of Imidacloprid in pesticide formulations. Samples were diluted with $\mathrm{CHCl}_{3}$ and the FTIR spectra of samples and standards were obtained at a nominal resolution of $4 \mathrm{~cm}^{-1}$ from 4000 to $900 \mathrm{~cm}^{-1}$ accumulating 25 scans. Imidacloprid determination was based on the measure of either peak area from 1577 to $1567 \mathrm{~cm}^{-1}$ or peak height at $1572 \mathrm{~cm}^{-1}$, both corrected using a horizontal baseline defined at $1900 \mathrm{~cm}^{-1}$. The limits of detection achieved, of the order of $9 \mu \mathrm{g} \mathrm{g}^{-1}$, were appropriate for the determination of Imidacloprid in commercially available formulations. FTIR results were statistically comparable to those found by High Performance Liquid Chromatography (HPLC). The procedure developed reduces organic solvent consumption, per sample preparation, from $53 \mathrm{~mL}$ $\mathrm{CH}_{3} \mathrm{CN}$ required for $\mathrm{HPLC}$ to $2.5 \mathrm{~mL} \mathrm{CHCl}_{3}$, and reduces waste generation also increasing the sample measurement frequency from $10 \mathrm{~h}^{-1}$ to $60 \mathrm{~h}^{-1}$ as compared with the HPLC-UV reference method.

Keywords: Imidacloprid, pesticide formulations, FTIR, HPLC-UV

\section{Introduction}

Imidacloprid, 1-(6-chloro-3-pyridylmethyl)-Nnitroimidazolidin-2-ylideneamine, 1-[(6-chloro-3pyridinyl)methyl]-N-nitro-2-imidazolidinimine, (CAS 13826-41-3), is a general use pesticide, classified by the USA Environmental Protection Agency (EPA) in both toxicity class II and class III. ${ }^{1}$ This pesticide is found in a variety of commercial insecticides as soluble concentrate, concentrated suspension and as wettable powder in different concentrations between $20 \% \mathrm{~m} / \mathrm{v}$ and $70 \% \mathrm{~m} / \mathrm{m}^{2}$

Imidacloprid is a systemic, chloro-nicotinyl insecticide for soil, seed and foliar uses, which is employed for the

\footnotetext{
* e-mail: salvador.garrigues@uv.es
}

control of sucking insects including rice hoppers, aphids, thrips, whiteflies, termites, turf insects, soil insects and some beetles. It is commonly used on rice, cereal, maize, potatoes, vegetables, sugar beets, fruit, cotton, hops and turf, and is especially systemic when used for seed or soil treatment. The insecticidal effect of Imidacloprid is achieved through bioaccumulation of acetylcholine in the target insects. ${ }^{3}$

Imidacloprid has been determined at trace levels in different environmental and food samples by high performance liquid chromatography with either mass spectrometry (HPLC-MS) ${ }^{4-6}$ or UV detection (HPLC-UV) using conventional dispersive spectrometers ${ }^{7-10}$ or diode array detectors, ${ }^{11,12}$ with Imidacloprid being determined in water, ${ }^{4,9}$ fruits and vegetables ${ }^{5-7,10,12}$ and greenhouse air. ${ }^{11}$

Gas chromatography has been also employed for 
Imidacloprid determination in coffee, ${ }^{13}$ vegetables ${ }^{14}$ and water and soil ${ }^{15}$ using mass spectrometric detection (GC-MS).

Non-chromatographic methods developed for Imidacloprid determination were based on enzyme-linked immunosorbent assays (ELISA) $)^{16-18}$ and flow injection analysis with photochemically induced fluorescence detection (FIA-PIF). ${ }^{19}$

For the determination of Imidacloprid in formulated insecticides, the Collaborative International Analytical Council (CIPAC) recommended procedure ${ }^{20}$ is based on HPLC-UV and it seems to be that the most extended methodology for the analysis of pesticide formulations. ${ }^{21,22}$

Fourier Transform Infrared spectrometry (FTIR) provides highly useful information about the structure of analites and it can be used for both qualitative and quantitative analysis. ${ }^{23,24}$ Because of this we have developed a series of analytical methodologies for the FTIR determination of Fluometuron, ${ }^{25}$ Buprofezin, ${ }^{26}$ Folpet and Metalaxyl. ${ }^{27}$ However there is no analytical procedure proposed in the literature for the determination of Imidacloprid in pesticide formulations by FTIR.

One of the identity tests proposed by CIPAC $^{20}$ is based on the comparison of FTIR spectra of samples or technical standards with that of pure standard in the spectral region between 1700 and $1400 \mathrm{~cm}^{-1}$ using KBr discs. However, the possibilities of this technique for the quantification of Imidacloprid were not explored.

The aims of this work are the development of a fast and environmentally friendly procedure, based on the use of FTIR, for the determination of Imidacloprid in commercial formulations which could be applied for quantitative purposes in both commercial formulations and technical products.

\section{Experimental}

\section{Apparatus and reagents}

A Nicolet (Madison, WI, USA) Magna 750 FTIR spectrometer, equipped with a temperature-stabilized deuterated tryglycine sulfate (DGTS) detector and controlled with Nicolet Omnic 2.1 (Madison, WI, USA), was employed for spectral measurements of $\mathrm{CHCl}_{3}$ solutions of Imidacloprid using a micro flow cell with a pathlength of $0.11 \mathrm{~mm}$ (Graseby-Specac, Orpinghton, UK) with $\mathrm{ZnSe}$ and $\mathrm{CaF}_{2}$ windows.

For introduction of samples and standards into the flow cell a Gilson Minipuls 2 peristaltic pump (Villiers-le-Bel, France) equipped with solvent resistant viton tubes of 3 $\mathrm{mm}$ od and $1 \mathrm{~mm}$ id was employed. The connection between the cell and the peristaltic pump was made using a $0.8 \mathrm{~mm}$ id PTFE tube.

A Hewlett-Packard HPLC Series 1050 High Performance Liquid Chromatograph, equipped with a Kromasil C-18, $5 \mu \mathrm{m}$ particle diameter, $250 \times 4.6 \mathrm{~mm}$ id column, and a variable wavelength UV-Vis detector, was also employed for the analysis of insecticide formulations, this methodology being employed as a reference for the validation of the FTIR measurements.

The Imidacloprid standard $(99.9 \% \mathrm{~m} / \mathrm{m})$ was purchased from Fluka (Buchs, Switzerland). Analytical grade chloroform stabilized with $150 \mathrm{mg} \mathrm{L}^{-1}$ amylene and HPLC grade acetonitrile were supplied by Scharlau (Barcelona, Spain) and were employed for the preparation of samples and standards, also using Milli-Q grade water for the mobile phase.

Imidacloprid, $20 \%(\mathrm{~m} / \mathrm{v})$ soluble concentrate commercial formulations, were obtained directly from the Spanish market.

\section{Reference procedure}

Weigh accurately $40 \mathrm{mg}$ of sample and dilute with $\mathrm{CH}_{3} \mathrm{CN}$ in a $25 \mathrm{~mL}$ volumetric flask, sonicating during 5 min in an ultrasound water bath. Dilute $1 \mathrm{~mL}$ of this solution to $25 \mathrm{~mL}$ and filter through a $0.22 \mu \mathrm{m}$ nylon filter. Inject $20 \mu \mathrm{L}$ of this latter solution in the chromatographic system using a 60:40 acetonitrile:water mobile phase at 1 $\mathrm{mL} \mathrm{min}^{-1}$ Imidacloprid being determined in the isocratic mode by absorbance measurements at $285 \mathrm{~nm}$. For the quantification of Imidacloprid, peak areas obtained at a retention time of $3.5 \mathrm{~min}$ for the samples were interpolated using external calibration established using standard solutions of Imidacloprid in acetonitrile over the concentration range from 3 to $30 \mu \mathrm{g} \mathrm{mL}^{-1}$.

\section{Recommended procedure}

Weigh accurately $20 \mathrm{mg}$ of sample and dilute with $4 \mathrm{~g}$ chloroform using ultrasonic agitation for $5 \mathrm{~min}$. Filter this solution through a $0.22 \mu \mathrm{m}$ nylon filter and aspirate directly into the FTIR measurement cell by using a peristaltic pump. The FTIR spectra were obtained, from 4000 to $860 \mathrm{~cm}^{-1}$, in the stopped-flow mode at $4 \mathrm{~cm}^{-1}$ nominal resolution, accumulating 25 scans using, as a background, the cell filled with $\mathrm{CHCl}_{3}$

The concentration of Imidacloprid in the samples was obtained by interpolation of peak areas from 1577 to 1567 $\mathrm{cm}^{-1}$ with an horizontal baseline fixed at $1900 \mathrm{~cm}^{-1}$ using external calibration established under the same conditions for Imidacloprid standards in a concentration range from 0.6 to $3.3 \mathrm{mg} \mathrm{g}^{-1}$. 


\section{Results and Discussion}

\section{FTIR spectra of Imidacloprid}

Figure 1 shows the FTIR spectra, in the wavenumber region from 2000 to $950 \mathrm{~cm}^{-1}$, of a chloroform solution of Imidacloprid at $3.3 \mathrm{mg} \mathrm{g}^{-1}$, a sample solution containing $0.8 \mathrm{mg} \mathrm{g}^{-1}$ Imidacloprid and a technical product solution containing $4.0 \mathrm{mg} \mathrm{g}^{-1}$ of Imidacloprid.

The spectra of both the technical product and the pure standard solution in $\mathrm{CHCl}_{3}$ present the same absorption bands, corresponding to the Imidacloprid molecule. On the other hand, it can be seen that the presence of different excipients in the formulation provide additional bands which, to a large extend, produce spectral differences between the FTIR spectra of the samples and the standards. Despite that, the bands at 1572 and $1548 \mathrm{~cm}^{-1}$ due to the $=\mathrm{CH}$ - stretching of the pyridine group, are clearly observed in all cases and seem to be free from matrix interferences.

The $-\mathrm{NO}_{2}$ symmetric stretching band located at $1300-$ $1250 \mathrm{~cm}^{-1}$, while the bands in the region between 1420 and $1500 \mathrm{~cm}^{-1}$, and that at $1109 \mathrm{~cm}^{-1}$, which are probably due to the aromatic $=\mathrm{CH}$ - and to the aryl- $\mathrm{Cl}$ stretching, respectively, ${ }^{28}$ seem to be affected by the formulation components and thus can not be employed for Imidacloprid determination without carrying out matrix removal.

\section{Selection of the appropriate bands}

As can be seen in Figure 1 the bands at 1572 and 1548 $\mathrm{cm}^{-1}$ are the bands of Imidacloprid which are clearly isolated and, apparently, do not overlap with any band of the different excipients in the formulated samples.

Thus, these bands were selected for Imidacloprid measurements. To obtain the best analytical performance of the FTIR determination of Imidacloprid, the use of peak height and peak area were evaluated, also using different baseline corrections.

Table 1 summarizes the main characteristics of the different regression lines found using the $1572 \mathrm{~cm}^{-1}$ and the $1548 \mathrm{~cm}^{-1}$ bands. As it can be seen, the band at $1548 \mathrm{~cm}^{-1}$ provides a reduced sensitivity and a high limit of detection, also involving a reduced linearity to the calibration lines, as compared with results found using the band at $1572 \mathrm{~cm}^{-1}$. For this latter band the regression lines had linear coefficients higher than 0.9999 showing the good linearity of the fits. The limits of detection obtained for the latter band ranged from 4 to $9 \mu \mathrm{g} \mathrm{g}^{-1}$, from 0.04 to $0.1 \% \mathrm{~m} / \mathrm{v}$ in the formulated pesticide, being thus appropriate for the determination of Imidacloprid in formulations. On the other hand the use of peak areas does not significantly improve the limits of detection despite the higher sensitivities found when peak areas is employed. Thus the use of either peak height at $1572 \mathrm{~cm}^{-1}$ or peak area from 1577 to $1567 \mathrm{~cm}^{-1}$, both corrected using an horizontal baseline defined at $1900 \mathrm{~cm}^{-1}$ are indicated, because these measurement conditions provide the lowest RSD values, and limits of detection of 9 and $6 \mu \mathrm{g} \mathrm{g}^{-1}$, respectively, which are equivalent to 0.1 and $0.07 \% \mathrm{~m} / \mathrm{v}$ of Imidacloprid in the original sample when using a sampling mass of $20 \mathrm{mg}$.

In the selected conditions the regression lines obtained using an external calibration set were comparable with those

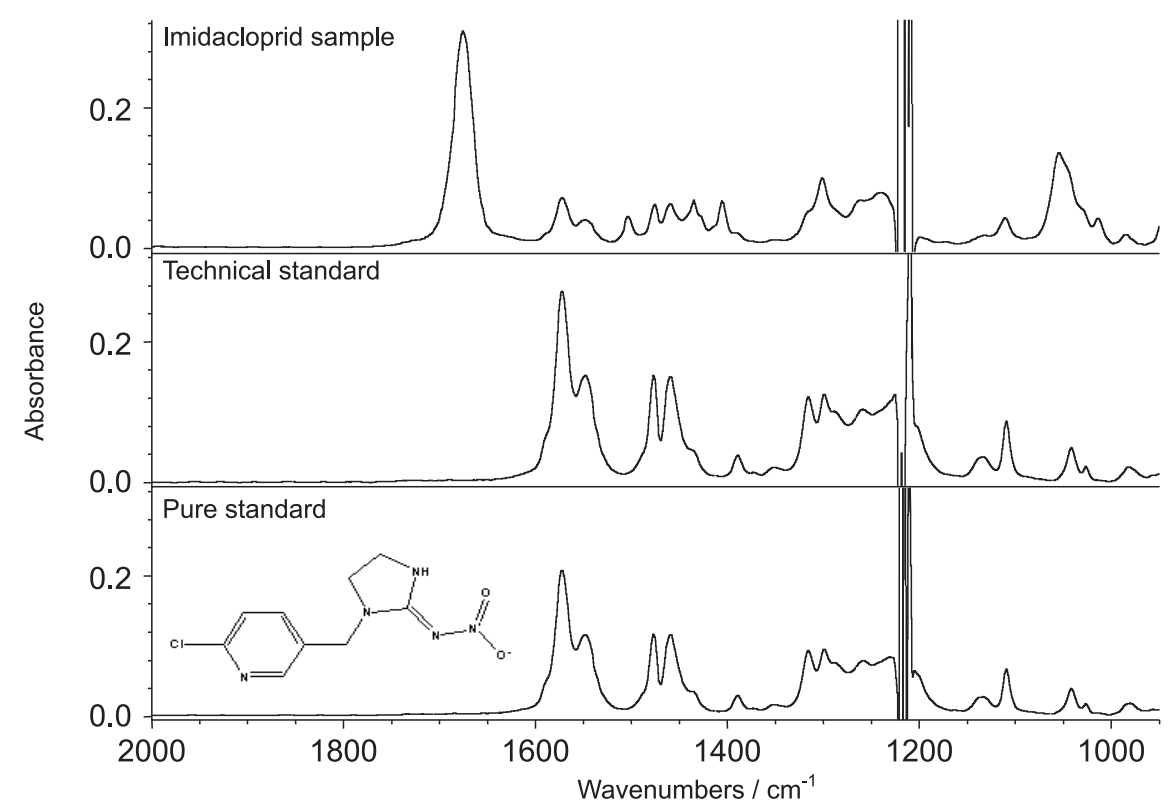

Figure 1. FTIR spectra of Imidacloprid. Note: Spectra were obtained in $\mathrm{CHCl}_{3}$ solutions containing 0.8 , 4.0 and 3.3 mg $\mathrm{g}^{-1}$ Imidacloprid of a pesticide formulation, a technical standard and a pure standard respectively. 
Table 1. Imidacloprid regression lines ${ }^{\mathrm{a}}$ obtained using peak area and peak height measurements for different band and using different baseline criteria

\begin{tabular}{|c|c|c|c|c|c|c|c|c|c|}
\hline \multirow[b]{2}{*}{$\begin{array}{l}\text { Band } \\
\left(\mathrm{cm}^{-1}\right)\end{array}$} & \multirow[b]{2}{*}{$\begin{array}{l}\text { Measurement } \\
\text { mode }\end{array}$} & \multirow[b]{2}{*}{$\begin{array}{l}\text { Wavelenght } \\
\text { region }\left(\mathrm{cm}^{-1}\right)\end{array}$} & \multirow[b]{2}{*}{$\begin{array}{l}\text { Baseline } \\
\left(\mathrm{cm}^{-1}\right)\end{array}$} & \multicolumn{3}{|c|}{ Regression line $\left.\left(\mathrm{Abs}=\mathrm{a}+\mathrm{b} \mathrm{C}_{(\mathrm{mg/g}}\right)\right)$} & \multicolumn{2}{|c|}{ L.O.D. } & \multirow[t]{2}{*}{$\%$ RSD } \\
\hline & & & & $\mathrm{a} \pm \mathrm{s}_{\mathrm{a}}$ & $\mathrm{b} \pm \mathrm{s}_{\mathrm{b}}$ & $\mathrm{r}^{2}$ & $\mu \mathrm{g} \mathrm{g}^{-1, \mathrm{~b}}$ & $\% \mathrm{~m} / \mathrm{v}^{\mathrm{c}}$ & \\
\hline \multirow[t]{6}{*}{1572} & $\mathrm{H}^{\mathrm{d}}$ & 1572 & 1900 & $0.0000 \pm 0.0005$ & $0.0625 \pm 0.0003$ & 0.9999 & 9 & 0.1 & 0.2 \\
\hline & $\mathrm{A}^{\mathrm{e}}$ & $1577-1567$ & 1900 & $-0.001 \pm 0.005$ & $0.558 \pm 0.002$ & 0.9999 & 6 & 0.1 & 0.2 \\
\hline & $\mathrm{H}$ & 1572 & 1520 & $-0.0004 \pm 0.0004$ & $0.0586 \pm 0.0002$ & 0.99991 & 6 & 0.1 & 0.6 \\
\hline & A & $1577-1567$ & 1520 & $-0.006 \pm 0.004$ & $0.521 \pm 0.002$ & 0.9999 & 8 & 0.1 & 0.6 \\
\hline & $\mathrm{H}$ & 1572 & $1614-1520$ & $-0.0002 \pm 0.0004$ & $0.0593 \pm 0.0002$ & 0.99992 & 5 & 0.1 & 0.4 \\
\hline & A & $1577-1567$ & $1614-1520$ & $-0.003 \pm 0.004$ & $0.527 \pm 0.002$ & 0.99991 & 3 & 0.04 & 0.4 \\
\hline \multirow[t]{2}{*}{1548} & $\mathrm{H}$ & 1548 & 1750 & $0.003 \pm 0.001$ & $0.0316 \pm 0.0006$ & 0.994 & 42 & 0.5 & 0.4 \\
\hline & A & $1553-1543$ & 1750 & $0.02 \pm 0.01$ & $0.296 \pm 0.006$ & 0.994 & 26 & 0.3 & 0.2 \\
\hline
\end{tabular}

a Calibration curve obtained for five standards of Imidacloprid at concentrations ranging from 0 to $3.30 \mathrm{mg} \mathrm{g}^{-1}$; ${ }^{\mathrm{b}}$ Limit of detection established from six independent measurements of a blank solution and a probability level of $99.6 \%(k=3) ;{ }^{c}$ Limit of detection in the original sample established from six independent measurements of a blank solution and a probability level of $99.6 \%(k=3)$ for a sample mass of $20 \mathrm{mg} ;{ }^{\mathrm{d}} \mathrm{H}=\mathrm{Peak}$ height; ${ }^{\mathrm{e}} \mathrm{A}=$ Peak area.

found by standard addition, which were $\mathrm{A}_{1577-1567}=(0.045 \pm$ $0.001)+(0.559 \pm 0.004) \mathrm{C}_{\mathrm{IMID}}\left(\mathrm{mg} \mathrm{g}^{-1}\right)$, with a regression coefficient $\mathrm{r}^{2}=0.9993$, and $\mathrm{H}_{1757}=(0.052 \pm 0.002)+(0.062$ $\pm 0.001) \mathrm{C}_{\mathrm{IMID}}\left(\mathrm{mg} \mathrm{g}^{-1}\right)$, with a regression coefficient $\mathrm{r}^{2}=$ 0.9992 , thus indicating the absence of matrix effects.

\section{Measurement conditions}

In order to select the most appropriate measurement conditions for the FTIR determination of Imidacloprid, the effect of using different nominal resolution values was studied and also that of the number of accumulated scans per spectrum on the signal to noise ratio of the Imidacloprid band at $1572 \mathrm{~cm}^{-1}$.
The effect of the nominal resolution on the spectral size and shape of the bands of Imidacloprid in $\mathrm{CHCl}_{3}$ is shown in Figure 2. From the inset the effect of the resolution on the peak height at $1572 \mathrm{~cm}^{-1}$, corrected with a horizontal baseline established at $1900 \mathrm{~cm}^{-1}$ is observed. The use of a high value of nominal resolution can not be recommended, because of the low sensitivity achieved and the deformation of the absorption bands, due to the low collection time required and the low noise obtained. A nominal resolution of $4 \mathrm{~cm}^{-1}$ was chosen, which provides good sensitivity, with a loss of only a $2.4 \%$ with respect to that found using $1 \mathrm{~cm}^{-1}$, and implies a $50 \%$ reduction of the acquisition time, thus increasing the sample throughput with a small sensitivity loss.

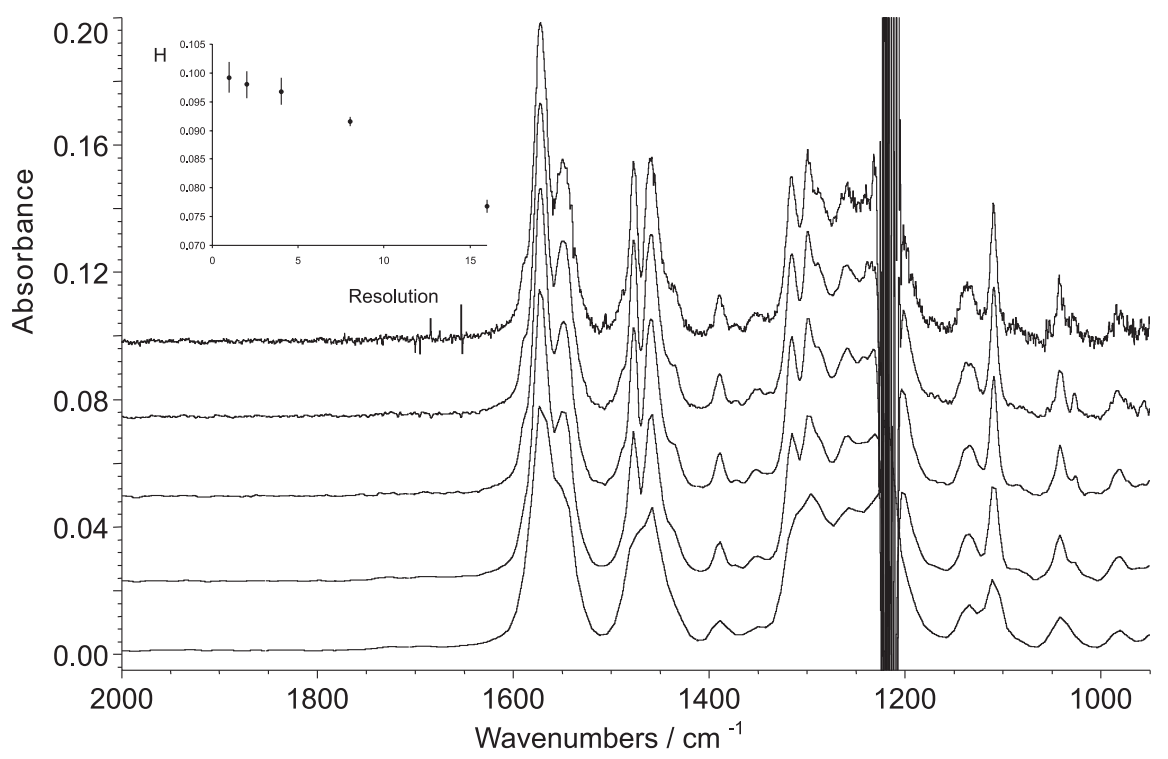

Figure 2. FTIR spectra of a standard solution of Imidacloprid in $\mathrm{CHCl}_{3}\left(1.7 \mathrm{mg} \mathrm{g}^{-1}\right)$ measured using 1, 2, 4, 8 and $16 \mathrm{~cm}^{-1}$ nominal resolution values (from the top to the bottom). Inset: Effect of the resolution on the peak height at $1572 \mathrm{~cm}^{-1}$ corrected using a horizontal baseline at $1900 \mathrm{~cm}^{-1}$. 
Figure 3 shows, for a nominal resolution of $4 \mathrm{~cm}^{-1}$, the effect of increasing the number of scans, from 5 to 50 , on the noise measured as root mean square (RMS) of absorbance signals of pure $\mathrm{CHCl}_{3}$ in the region between 1577 and $1567 \mathrm{~cm}^{-1}$. In order to ensure a compromise between sample measurement frequency and signal to noise ratio, 25 scans were selected for further measurements.

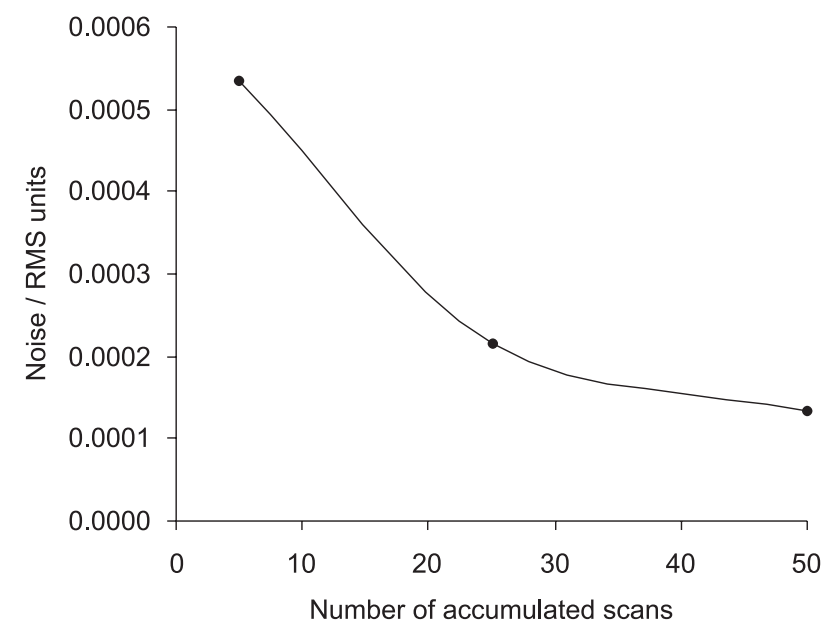

Figure 3. Effect of the number of accumulated scans on the spectral noise of FTIR spectra of a $\mathrm{CHCl}_{3}$ blank solution, measured as root mean square (RMS) of the absorbance signals in the region between 1577 to $1567 \mathrm{~cm}^{-1}$.

\section{Comparison between HPLC and FTIR methods}

Table 2 shows the data found for the determination of Imidacloprid in three commercially available pesticide formulation samples, obtained by using both the FTIR procedure and the HPLC-UV reference method and, as can be seen, statistically comparable data were found by both procedures using either peak height or peak area measurements for the band at $1572 \mathrm{~cm}^{-1}$, thus showing that the accuracy of the developed procedure is comparable to that found by the CIPAC recommended strategy. Additionally a higher repeatability found on using FTIR measurements can be noticed compared to that found by

Table 2. Determination of Imidacloprid in pesticide formulations analyzed by the FTIR procedure developed and by the HPLC-UV reference method

\begin{tabular}{|c|c|c|c|}
\hline \multicolumn{4}{|c|}{ Imidacloprid $(\% \mathrm{~m} / \mathrm{v})^{\mathrm{a}}$} \\
\hline & \multicolumn{2}{|c|}{ FTIR } & HPLC-UV \\
\hline Sample & HEIGHT $^{\mathrm{b}}$ & AREA $^{\mathrm{c}}$ & \\
\hline 1 & $20.07 \pm 0.07^{\mathrm{c}}$ & $20.00 \pm 0.08$ & $20.1 \pm 0.4$ \\
\hline 2 & $20.00 \pm 0.04$ & $20.01 \pm 0.02$ & $20.2 \pm 0.1$ \\
\hline 3 & $20.0 \pm 0.2$ & $20.0 \pm 0.1$ & $20.1 \pm 0.2$ \\
\hline
\end{tabular}

HPLC, probably due to the use of the successive dilutions involved in the chromatographic procedure.

Table 3 summarizes the main analytical parameters found using the developed procedure compared with those of the reference HPLC-UV method. The low limit of detection achieved by HPLC-UV makes it appropriate for the determination of Imidacloprid at low concentration levels as, for example, in treated crops or waste waters, but the concentration level at which HPLC works also requires a high sample dilution for the analysis of pesticide formulations which increases waste generation and degrades the precision of the method.

Table 3. Comparison of the analytical figures of merit of the FTIR method and the HPLC-UV procedure

\begin{tabular}{|c|c|c|}
\hline Analytical parameters & HPLC-UV reference & FTIR $^{a}$ \\
\hline Intercept $\left(a \pm s_{a}\right)$ & $0.7 \pm 0.3$ & $-0.001 \pm 0.005$ \\
\hline Slope $\left(b \pm s_{b}\right)$ & $\begin{array}{l}31.67 \pm 0.02 \\
(\text { au mg-1 } 1)\end{array}$ & $\begin{array}{l}0.558 \pm 0.002 \\
\left(\text { au mg } \mathrm{mg}^{-1} \mathrm{~g}\right)\end{array}$ \\
\hline $\begin{array}{l}\text { Correlation } \\
\text { coefficient }\left(r^{2}\right)\end{array}$ & 0.99998 & 0.9999 \\
\hline Concentration range & $0-30\left(\mu \mathrm{g} \mathrm{ml}^{-1}\right)$ & $0-3.3\left(\mathrm{mg} \mathrm{g}^{-1}\right)$ \\
\hline$\% \mathrm{RSD}^{\mathrm{b}}$ & 0.05 & 0.2 \\
\hline $\operatorname{LOD}\left(\mu \mathrm{g} \mathrm{g}^{-1}\right)$ & 0.03 & 9 \\
\hline $\operatorname{LOD}(\% \mathrm{~m} / \mathrm{v})$ & 0.03 & 0.1 \\
\hline$\% \mathrm{RSD}^{\mathrm{c}}$ & 1.1 & 0.3 \\
\hline
\end{tabular}

${ }^{a}$ Using peak area values measured between 1577 and $1567 \mathrm{~cm}^{-1}$ with a baseline established at $1900 \mathrm{~cm}^{-1}$; ${ }^{\text {b }}$ Relative standard deviation values obtained from six measurements of a standard solution located at the middle of the calibration line.; ${ }^{\mathrm{c}}$ Mean relative standard deviation obtained for three replicate analysis of three commercially available samples containing approximately $20 \% \mathrm{~m} / \mathrm{m}$ of Imidacloprid.

The solvent volume employed for the measurement of a single sample was $2.5 \mathrm{~mL}$ of $\mathrm{CHCl}_{3}$ for FTIR determination and $53 \mathrm{~mL}$ of $\mathrm{CH}_{3} \mathrm{CN}$ for HPLC, it also being necessary, in this later case, the use of a mobile phase which increases waste generation in $60 \mathrm{~mL} \mathrm{~h}^{-1}$. So the FTIR procedure can be considered an environmentally friendly alternative to the use of HPLC-UV in the analysis of formulations. On the other hand, the sample throughput of the FTIR procedure was 60 samples $\mathrm{h}^{-1}$, compared to $10 \mathrm{~h}^{-1}$ for HPLC, thus increasing laboratory efficiency and providing faster methodology.

\section{Conclusions}

The FTIR procedure developed for the quantitative determination of Imidacloprid in pesticide formulations provides statistically comparable results to those found by using a reference HPLC procedure and clearly reduces sample handling by reducing the need of sample dilution resulting in a significant reduction of waste generation and offering a faster alternative method. 


\section{Acknowledgements}

Authors acknowledge the financial support of the Generalitat Valenciana Project GV01-249 and the grant provided by the Laboratorio de Higiene Laboral y Ambiental of the Universitat de Valencia and Laboratorios Ibáñez to carry out this study. S. Armenta acknowledges the FPU Grant of the Ministerio de Educación, Cultura y Deporte de España (Ref. AP2002-1874).

\section{References}

1. Meister, R.T., ed.In Farm Chemicals Handbook 1994; Meister Publishing Company: Willoughby, OH, 1994.

2. de Liñan, C.; Vademecum de Productos Fitosanitarios y Nutricionales, Ed. Agrotécnica S. L.: Madrid, 2000.

3. Kidd, H.; James, D. R., eds. In The Agrochemicals Handbook, $3^{\text {rd }}$ ed., Royal Society of Chemistry Information Services: Cambridge, UK, 1991

4. Hernandez, F.; Sancho, J. V.; Pozo, O.; Lara, A.; Pitarch, E.; J. Chromatogr. A 2001, 939, 1.

5. Pous, X.; Ruiz, M. J.; Pico, Y.; Font, G.; Fresenius' J. Anal. Chem. 2001, 371, 182.

6. Fernandez-Alba, A. R.; Tejedor, A.; Aguera, A.; Contreras, M.; Garrido, J.; J. AOAC. Int. 2000, 83, 748.

7. Dai, H.; Li, Y. J; Zhang, Y.; Fenxi Ceshi Xuebao 2002, 21, 70. (CA 136:305.493)

8. He, J.; Chang, J. B.; Guo, R. Y.; Liu, P.; Lin, S. F.; Chen, R. F.; Wang, Q. A.; Sерu. 2000, 18, 181.

9. Guiberteau-Cabanillas, A.; Galeano-Diaz, T.; Mora-Diez, N.; Parrilla-Vazquez, P.; Salinas-Lopez, F.; Talanta 2001, 53, 943.

10. Ishii, Y.; Kobori, I.; Araki, Y.; Kurogochi, S.; Iwaya, K.; Kagabu, S.; J. Agric. Food Chem. 1994, 42, 2917.

11. Garrido-Frenich, A.; Egea-Gonzalez, F. J.; Martinez-Vidal, J. L.; Parrilla-Vazquez, P.; Mateu-Sanchez, M. J.; J. Chromatogr. A 2000, 869, 497.
12. Fernandez-Alba, A. R.; Valverde, A.; Aguera, A.; Contreras, M.; Chiron, S.; J. Chromatogr. A 1996, 721, 97.

13. Lodevico, R. G.; Li, Q. X.; Anal. Lett. 2002, 35, 315.

14. Navalon, A.; Gonzalez-Casado, A.; El-Khattabi, R.; Vilchez, J. L.; Fernandez-Alba, A. R.; Analyst 1997, 122, 579.

15. Vilchez, J. L.; El-Khattabi, R.; Fernandez, J.; Gonzalez-Casado, A.; Navalon, A.; J. Chromatogr. A 1996, 746, 289.

16. Lee, J. K.; Ahn, K. C.; Park, O. S.; Kang, S. Y.; Hammock, B. D.; J. Agric. Food. Chem. 2001, 49, 2159.

17. Wanatabe, S.; Ito, S.; Kamata, Y.; Omoda, N.; Yamazaki, T.; Munakata, H.; Kaneko, T.; Yuasa, Y.; Anal. Chim. Acta 2001, 427, 211.

18. Li, K.; Li, Q. X.; J. Agric. Food. Chem. 2000, 48, 3378.

19. Sarkar, M. A.; Biswas, P. K.; Roy, S.; Kole, R. K.; Chowdhury, A.; Bull. Environ. Contam. Toxicol. 1999, 63, 604.

20. Collaborative International Pesticides Analytical Council (CIPAC) Handbook; CIPAC Ltd; 1994, Volume H, 185.

21. Li, L. S.; Fenxi. Shiyanshi 1998, 17, 60. (CA 130: 91.577)

22. Macke, M. M.; J. AOAC Int. 1998, 81, 344.

23. Cadet, F.; de la Guardia, M., In Quantitative Analysis, Infrared. Encyclopedia of Analytical Chemistry. Meyers, R. A., ed., John Wiley \& Sons, Ltd: Chichester, 2000.

24. Garrigues, S.; de la Guardia, M.; Infrared Quantitative Analysis; Encyclopedia of Analytical Chemistry, John Wiley \& Sons, Ltd: Chichester, 2002, vol. 2.

25. Armenta S.; Quintás G.; Moros J.; Garrigues S.; de la Guardia M.; Anal. Chim. Acta 2002, 468, 81.

26. Quintás G.; Morales-Noé A.; Parrilla C.; Garrigues S.; de la Guardia M.; Vib. Spectroscopy 2003, 31, 63.

27. Quintás, G.; Armenta, S.; Morales-Noé, A.; Garrigues, S.; de la Guardia, M.; Anal. Chim. Acta 2003, 480, 11.

28. Lin-Vien, D.; Colthup, N.B.; Fateley, W.G.; Grasselli, J.G.; Infrared and Raman Characteristic Frequencies of Organic Molecules. Academic Press: London, 1991, 296.

Received: February 25, 2003 Published on the web: April 6, 2004 